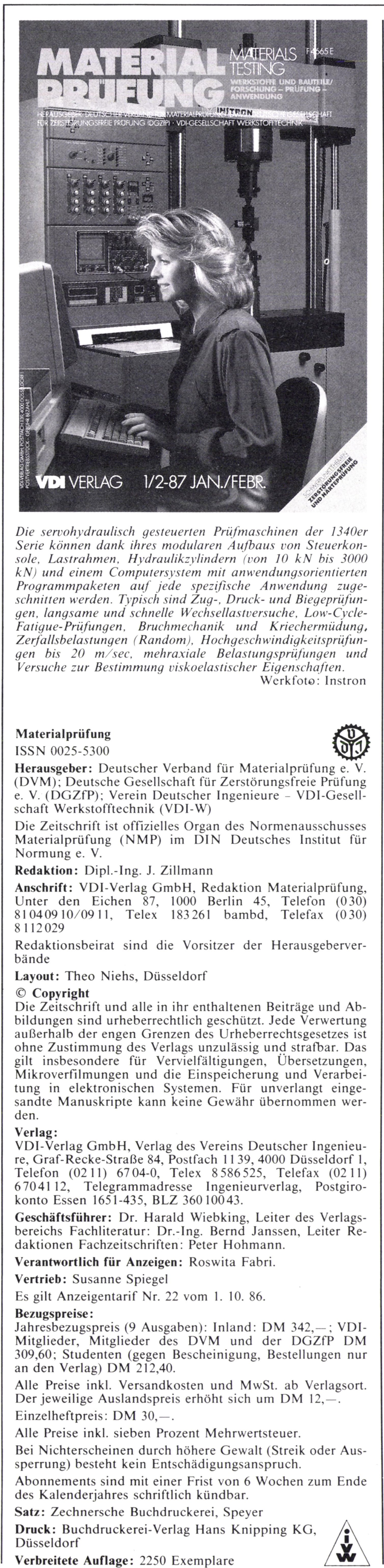

G. Pfister, P. Maier, G. Hehn, G. Stier, W. Kegreiss

Ein Neutronentomograph zum Einsatz für die Werkstoffprüfung

H.-A. Jestrich, W. Prestel, D. Heinrich, W. Schmalenbeck

Die Bedeutung der Ultraschall-Ersatzreflektorgröße

für die Bruchmechanik, untersucht an schweren

Schmiedestücken für Turbomaschinen

P. A. Makris

Zur gesetzmäßigen Einteilung des Rißweges bei

Rißlängenmessungen unter dynamischer Belastung

H. Dambacher

Die Änderung der Kalibrierbedingungen für

Härtevergleichsplatten nach den Rockwell-Verfahren im Rahmen der ISO-Normung

und ihre Auswirkung auf die ermittelten Härtewerte

\title{
H. Montagu-Pollock
}

Härteprüfung bei Eindringtiefen im Submikrometerbereich 22

$$
\text { H. Morlo }
$$

Anhebung des axialen Auflösungsvermögens bei der

Ultraschallprüfung durch gesteuerte Sendesignale

R. Marappan, A. Ramamohana Rao

Wear in lubricated plain bearings - an overview

Ausstellungsbericht von J. Zillmann

Rückblick auf die Interkama 86, Düsseldorf

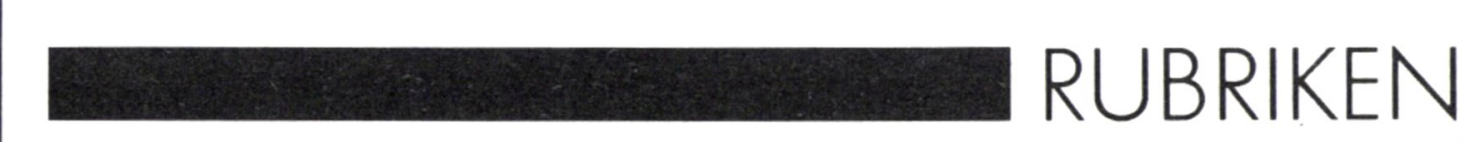

Aus den Herausgebergesellschaften/Fachnachrichten 1

Persönliches

Normen und Richtlinien

Geräte und Verfahren

\section{Wenn es um die Wirtschaftlichkeit Ihrer Werkstoff-Prüfung geht...}

FRANK-Prüfgeräte für die zerstörende Werkstoffprüfung mit analoger und digitaler Meßwert-Erfassung mit Meßwertrechnern

KARL FRANK GMBH

Postfach $1320 \cdot 6940$ Weinheim

prüfen

messen

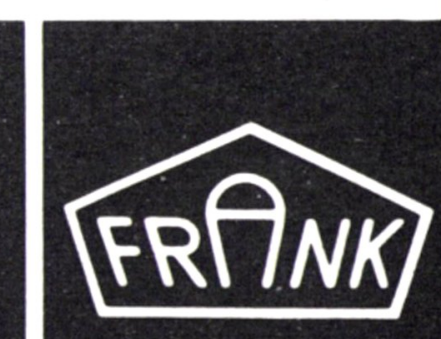


G. Pfister, P. Maier, G. Hehn, G. Stier, W. Kegreiss:

Ein Neutronentomograph zum Einsatz für die Werkstoffprüfung

Materialprüf. 29 (1987) Nr. 1-2 S. 8/12

(6 Fig. 16 Ref.)

Ein Neutronen-Computertomograph (CT) wurde am IKE der Univ. Stuttgart entwickelt, mit dem Tomographiebilder zu erzeugen sind, die den Qualitätsanforderungen der zerstörungsfreien Werkstoffprüfung genügen. Sowohl kleine Fehler mit großen Kontrasten als auch kleine Dichteänderungen konnten abgebildet werden. Starke Dichtegradienten in der Probe führen bei schnellen Neutronen kaum zu Bildartefakten. Aufgrund der Wechselwirkung der Neutronen mit den Atomkernen sind die Bildinformationen und Kontrastverhältnisse im Vergleich $\mathrm{zu}$ Strahlenarten, die mit der Elektronenhülle wechselwirken, sehr verschieden. Insbesondere können wasserstoffhaltige Materialien gut dargestellt werden. Schnelle Neutronen eignen sich wegen ihres hohen Durchdringungsvermögens besonders zur Untersuchung dicker Proben. Zur Prüfung von kleinen Proben ist vorgesehen, auch thermische Neutronen in die CT-Messungen mit aufzunehmen.

\section{H.-A. Jestrich, W. Prestel, D. Heinrich, W. Schmalenbeck:}

Die Bedeutung der Ultraschall-Ersatzreflektorgröße für die Bruchmechanik, untersucht an schweren Schmiedestücken für Turbomaschinen

Materialprüf. 29 (1987) Nr. 1-2 S. 13/16

(7 Fig. 1 Tab. 16 Ref.)

Im Rahmen einer Gemeinschaftsarbeit wurde untersucht, inwieweit mit einer Prüfung mit Ultraschall (US) Herstellungsfehler hinsichtlich Größe und Verteilung beschrieben werden können und die bisherigen Annahmen der Bruchmechanik unter Zugrundelegung betrieblicher Beanspruchung mit dem tatsächlichen Verhalten der Fehler übereinstimmen. Dazu wurden aus großen Schmiedestücken, die aufgrund unzulässiger US-Befunde zu Ausschuß erklärt worden waren, Proben mit Fehlstellen gezielt entnommen. Diese wurden in Analogie zu den Start/Stop-Beanspruchungen von Turbomaschinen bis maximal zur Streckgrenze im Bereich bis zu 25000 Lastwechseln zyklisch beansprucht. Danach wurden die Proben aufgebrochen und die Ursprungsfehlstellen und das Rißwachstum exakt ausgemessen. Bei mehreren Untersuchungsschritten wurden jeweils Prüfungen mit US und z. T. mit Magnetpulver durchgeführt. Die US-Ersatzreflektorgröße kann als Grundlage für bruchmechanische Berechnungen dienen, da das auf ihrer Basis berechnete und vorhergesagte Rißwachstum größer als das Wachstum der Fehler war.

Panagiotis A. Makris:

Zur gesetzmäßigen Einteilung des Rißweges bei Rißlängenmessungen unter dynamischer Belastung

Materialprüf. 29 (1987) Nr. 1-2 S. 17/18

(2 Fig. 6 Ref.)

In den meisten Rißfortschrittsuntersuchungen werden Rißlängemessungen mit gleichmäßig geteilten Rißwegen durchgeführt. Je nach Art der Geschwindigkeitmessung, der angestrebten Meßgenauigkeit und der Blechdicke wird die Meßdichte festgelegt. Die Auswahl der Meßdichte beeinflußt offensichtlich die Genauigkeit der Berechnung der Rißgeschwindigkeit und wirkt sich somit auf die Zuverlässigkeit der Versuchsergebnisse aus.
G. Pfister, P. Maier, G. Hehn, G. Stier, W. Kegreiss:

A neutron tomography scanner for application in nondestructive testing

Materialprüf. 29 (1987) No. 1-2 p. 8/12

(6 Fig. 16 Ref.)

A neutron computer-tomograph scanner was developed at the IKE (Univ. Stuttgart). The equipment is transportable and can be used at different neutron sources. Neutron CT-images are presented in this paper showing that it is possible to get good results by using Neutron-CT in NDT. Small defects with high contrasts can be detected as well as larger defects with small differences in material density. The neutron CT images show nearly no artifacts even if large differences in absorption coefficients are present. Therefore the neutron CT technique can be used with advantage to examine strongly inhomogeneous samples as well as samples with large diameters.

Since the neutrons interact with the nuclei and not with the electron density the CT-images contain different information compared with $\mathrm{X}$ - and gamma-ray images. For the examination of small samples it is intended to use thermal neutrons for further CT-measurements too.

H.-A. Jestrich, W. Prestel, D. Heinrich, W. Schmalenbeck:

The importance of the ultrasonic equivalent reflector size to the fracture mechanics - tested on heavy forgings for turbine-generators

Materialprüf. 29 (1987) No. 1-2 p. 13/16

(7 Fig. 1 Tab. 16 Ref.)

As a group work it was investigated whether steelmaking defects in large forgings for turbine-generators can be evaluated especially regarding their size and distribution by means of conventional ultrasonics and whether the fracture mechanics methods used meet the real behaviour of such defects under fatigue loading. Specimens were machined from large forgings which had been rejected due to unacceptable ultrasonic indications. Simulating start/stop-cycles of turbine-generators the specimens were stressed in pulsating tension up to stress levels reaching the yield strength. After 25000 cycles the specimens were broken open and the real sizes of the original defects and the crack propagation were measured. During several investigation steps ultrasonic examinations and partially magnetic particle testing were performed. The results showed that the ultrasonic testing indication amplitude expressed as an equivalent flat bottom hole diameter can be used for fracture mechanics calculations since the real crack propagation was always less than the crack propagation predicted on the basis of the ultrasonic testing ut results.

Panagiotis A. Makris:

An analytical law for non-equidistance crack path subdivisions in crack propagation experiments

Materialprüf. 29 (1987) No. 1-2 p. 17/18

(2 Fig. 6 Ref.)

In fatigue crack propagation experiments with constant stress amplitude the crack path subdivisions influence the accuracy and the representation of the rate of crack propagation. In the present paper it is shown, that the crack path subdivisions law, based on stress distribution similarity by propagating crack, gives a near to linear relationship between the number of load-cycles and the serial number of subdivision. 
H. Dambacher:

Die Änderung der Kalibrierbedingungen für Härtevergleichsplatten nach den Rockwell-Verfahren im Rahmen der ISO-Normung und ihre Auswirkung auf die ermittelten Härtewerte

Materialprüf. 29 (1987) Nr. 1-2 S. 19/22 (1 Fig. 1 Tab. 2 Ref.)

Die Kalibrierbedingungen für Härtevergleichsplatten zur Untersuchung von Härteprüfgeräten nach den Rockwellverfahren wurden von der ISO (International Organization for Standardization) geändert. Diese Änderungen bewirken eine Verschiebung der Rockwell-Skalen hin zu höheren Härtewerten - insbesondere für Metalle niedrigerer Härte. Darüber hinaus wird die Meßunsicherheit beträchtlich vergrößert. So wird die Vergleichbarkeit von Härtewerten erschwert, und die weltweit angestrebte Harmonisierung der nationalen Skalen kann einen unnötigen empfindlichen Rückschlag erleiden.

Nachdruck dieser Inhaltsangaben ist gestatte

H. Montagu-Pollock:

Härteprüfung bei Eindringtiefen im Submikrometerbereich

Materialprüf. 29 (1987) Nr. 1-2 S. 22/23 (3 Fig.)

\section{Heinrich Morlo:}

Anhebung des axialen Auflösungsvermögens bei der Ultraschallprüfung durch gesteuerte Sendesignale

Materialprüf. 29 (1987) Nr. 1-2 S. 23/24 (2 Ref.)

R. Marappan, A. Ramamohana Rao:

Verschleiß in geschmierten ebenen Lagern - ein Überblick

Materialprüf. 29 (1987) Nr. 1-2 S. 25/27 (3 Fig. 2 Tab. 31 Ref.)

Ausstellungsbericht

J. Zillmann:

Rückblick auf die Interkama 86, Düsseldorf

Materialprüf. 29 (1987) Nr. 1-2 S. 28/40 (33 Fig.)

\section{H. Dambacher}

The modification of the calibration conditions for standardized blocks for the Rockwell hardness test in the field of ISO-work and the effect on the hardness values measured

Materialprüf. 29 (1987) No. 1-2 p. 19/22 (1 Fig. 1 Tab. 2 Ref.)

The calibration conditions concerning hardness test blocks used for the verification of hardness testing machines for the Rockwell test were modified by ISO. These modifications effect a shifting of the Rockwell scales in direction of higher hardness values, in particular affecting metals having a softer hardness. Moreover, the measurement uncertainty is increased considerably. Hence the comparability of hardness values is made more difficult, and the world-wide striving for harmonizing the national scales may suffer an unnecessary grievous reverse of progress.

These summaries may be republished

H. Montagu-Pollock:

Hardness testing at sub-micrometre depths

Materialprüf. 29 (1987) No. 1-2 p. 22/23 (3 Fig.)

Heinrich Morlo:

Increase of the axial disintegration capacity at the ultrasonic testing with controlled transmitting pulses

Materialprüf. 29 (1987) No. 1-2 p. 23/24 (2 Ref.)

R. Marappan, A. Ramamohana Rao:

Wear in lubricated plain bearings - an overview

Materialprüf. 29 (1987) No. 1-2 p. 25/27 (3 Fig. 2 Tab. 31 Ref.)

Exhibitions

J. Zillmann:

Review of the Interkama 86, Düsseldorf

Materialprüf. 29 (1987) No. 1-2 p. 28/40 (33 Fig.)

\section{INHALT DER NÄCHSTEN AUSGÄBE}

E. Neumann, B. Behrendt, A. Hecht: Nachweis von Korrosion (Spongiose) an den Innenwänden von Graugußrohren mit Hilfe einer rechnergeführten Ultraschallprüfeinrichtung (ABAKUS)
S. Rupp, K.-D. Becker, W. Gebhardt: J. Block, G. W. Ehrenstein: Ein Modell zur Rechnergestützte Modellierung von Ul- Korrelation zwischen Schadensmechanistraschallprüfanordnungen

G. Kohlhaas: Einfluß der Widerlagerreibung auf die Schlagarbeit beim Kerbschlagbiegeversuch. Teil 1: Theoretische Abschätzung men in Faserverbundwerkstoffen und Schallemissionsmessungen

M. Nowak: Über den Zerrüttungskoeffizienten von Kunststoffen - dargestellt am Beispiel von Polyamid
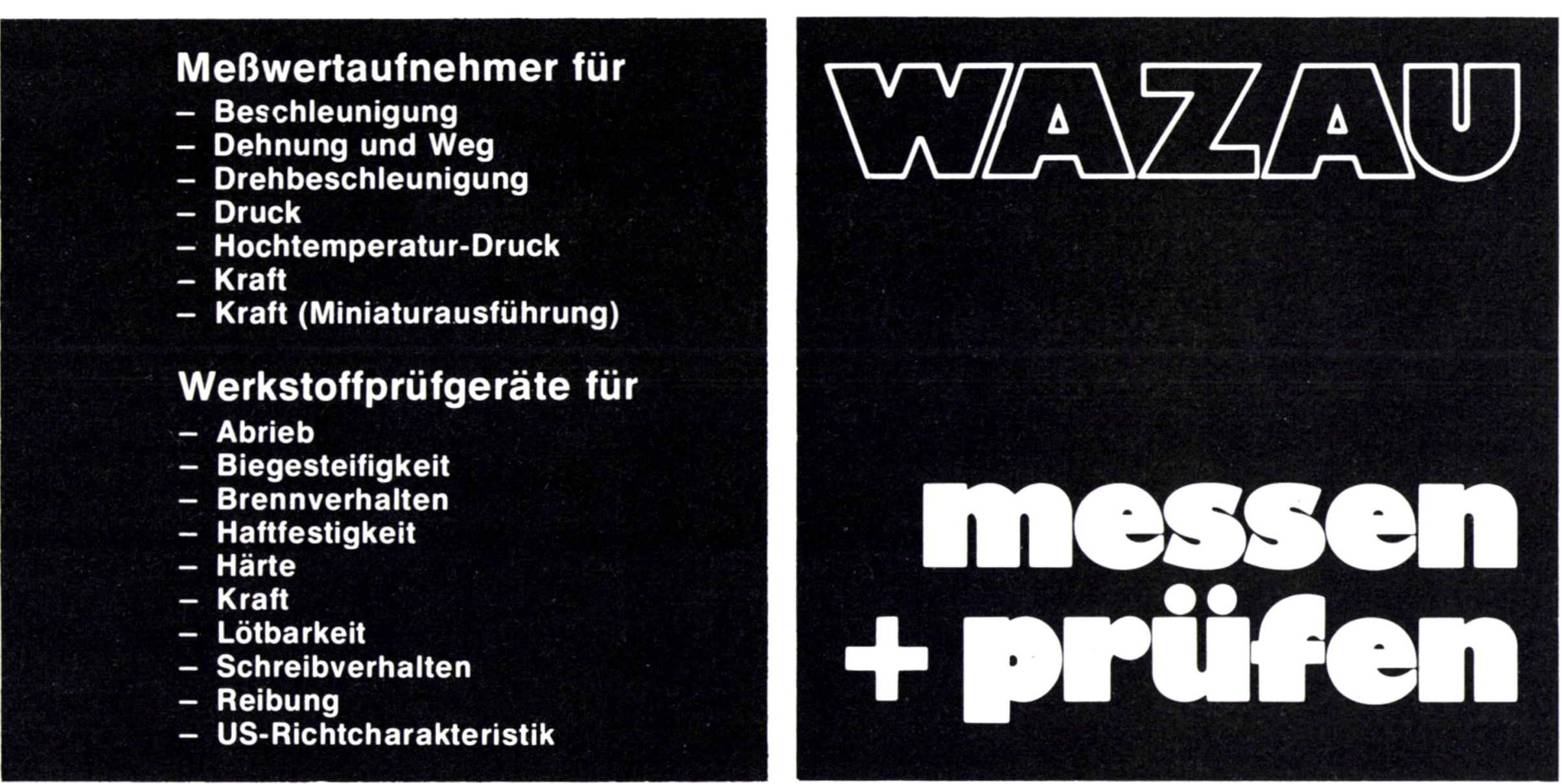

DR.-ING. GEORG WAZAU, KEPLERSTR. 12, D-1000 BERLIN 10

TEL. 0 30/3 4430 88/89 · TELEX 183304 wazau d 